\title{
RESEARCH OF THE PRESSING APPLIED BY THE NSA „VASSIL LEVSKI“ FOOTBALL TEAM, DURING THE NATIONAL STUDENT CHAMPIONSHIP OF BULGARIA
}

\author{
Georgi Ignatov, Emil Atanasov
}

\begin{abstract}
The present development of the football game inquires searching for mechanisms to improve the athletes'preparation in all of its aspects - technique, tactics, psyche. In this sense, good knowledge of each player's peculiarities in the implementation of the press actions would significantly contribute to the improvement of the tactical training of football players. Implementation of sports-pedagogical monitoring and video shooting of the NSA matches against the teams of the Sofia University "St. Kliment Ohridski" and University of Mining and Geology "St. Ivan Rilski". Games were a part of the 2016/2017 Bulgarian National Football Championship. Frequency analysis is used to process and analyze the results. The basic direction of this report is to examine and analyze the characteristics of the pressing application during two matches of the National Sports Academy's student football team. Basic part of the report is the characterization of the performing pressing by the types of football areas, as well as tracking the efficiency and dynamics of the football matches. Studying the specifics of performing pressing in the football game would help to improve the use of tactical training for football players.
\end{abstract}

Key words: football, pressing, students, specifics, effectiveness, analysis

\section{Introduction}

The typical features of modern football - intellect, creativity, athleticism and a high level of technical and tactical skills - present a number of challenges for the players and coaches. During the current stage of the game development it is no longer enough for players and coaches to have just practical experience. Serious and in-depth knowledge of all components of the game (including technique, tactics, physical ability, mental ability, physical recovery, etc.) is required. Since football is a team sport, tactical knowledge becomes extremely important. Taking this into account, knowing the specifics of applying pressing actions against the opponent would significantly help in improving the tactical preparation of the footballers.

Pressing in football is a tactical behaviour of the team which has lost the ball and is trying to get it back as fast as possible by limiting the time and space where the opponents plays in (Ангелов и кол., 1987; Шишков и кол., 1992).

Pressing i.e. actively pressing the player with ball is a powerful method for recovering possession of the ball and organising attacks. It has a very powerful emotional effect on the players and the audience (Гигов, 2002, 2004).

The author (Гигов, 1999, 2004), informs us about the strategy and the tactics of the game of football, the defence tactics, as well as about pressing, one of the main defensive actions in football. He offers ways for applying pressing and a method for improving it in competitive conditions, as well as a method for its registration. According to him the defence strategy is one of the most important factors which determine the sport result in football. The results of his study clearly show the importance of pressing for achieving effective and attractive modern football (Гигов, 2002). Another study (Гигов \& Гигова, 2000) determines the quantity and the effectiveness of the pressing actions of the elite European club teams which participate in the UEFA club competitions. In another paper (Гигов и кол., 2004), the authors explain the impact of activity and effectiveness of the use of pressure on the final position of the teams which qualified for the 2002 World Cup Finals. Other authors (Бъчваров, Димитров \& Гигов, 2008), competently inform us about the typical features of modern football and offer training drills for pressing and for pressing actions during set pieces.

The authors (Червеняков \& Цолов, 1999, 2000, 2001) inform us in a very detailed and methodical manner about the tactics necessary for playing good football, including pressing as a method for taking the ball from the opponent and coverage as a preparation for recovering the ball from the opponent. 
The study of the pressing used by the Bulgarian Women's National Football Team is explored in two research papers: one about the 2005 Albena International Tournament (Атанасов, 2005), and one about the Women's World Cup qualifiers during 2009/2010 (Атанасов, 2010).

The factors listed above were the reason we did this multi-component study intended to describe in detail the tactical preparation, including applying pressure, by the students of the football team of the Vassil Levski National Sports Academy (NSA).

The goal of the research paper is to study and analyse the specific characteristics of the use of pressing in two matches of the team of the National Sports Academy which takes part in the Bulgarian Student Football Championship.

To reach our goal we set the following tasks for ourselves:

1. To perform sport-pedagogic observation and to record the matches of the Vassil Levski National Sports Academy (NSA) team against the teams of the Sv. Kliment Ohridski Sofia University (SU) and the Sv. Ivan Rilski University of Mining and Geology (MGU) played in the National University Football Championship of Bulgaria during the 2016/2017 season;

2. to characterise the distribution of the pressing actions by type, by zones of execution, by effectiveness and by the dynamic during the matches;

3. Based on the results reached, to make an attempt to optimise the training and competition processes.

\section{Methods}

This study was conducted as follows: sport-pedagogic observation and video recording of the match between the NSA and the SU teams played on 27 March 2017 from 14:00 at the NSA stadium in Sofia, as well as the match between the MGU and the NSA teams played on 17 May 2017 from 18:00 at the Dragalevtsi stadium in Sofia. The two matches were played as part of the National University Football Championship of Bulgaria during the 2016/2017 season,, organised by Academic Association for University Sport (AUS) with the support of the Bulgarian Football Union (BFU), in which 16 teams took part during the same 2016/2017 season.
The subject of the study were the athletes from the representative student football teams of the NSA, the SU and the MGU.

The topic of the study was the use of pressing during the two matches by the players from the football teams of NSA, SU and MGU.

33 players took part in the study - 11 each from the teams of NSA, SU and MGU, they were the ones who played in the matches in question between these teams.

In order to find and classify the pressing actions by type, zone of execution, effectiveness and dynamic within the course of the matches, the results of the study were processed using variation analysis and the index method.

\section{Results and discussion}

In tables 1, 2 and 3 we have presented the results of the study of the pressing in the matches which were observed by us. Pressing was used most often by the MGU team against the NSA team (62 times). The NSA team used this tactic the least against the SU team (40 times). We think that these facts can be explained by the tasks set by the coaches, on one hand, and the level of the opponent, on the other.

The main goal and the most effective end of the pressing is taking the ball from the opponent (Table 1). The NSA team recorded the highest number of these by taking the ball from the opponent 16 times (30.8\%) during its match against the MGU. The SU team did this 15 times $(27.3 \%)$ in their game against the NSA, while the MGU recorded the worst number in this area in its match against the NSA team by taking the ball from its opponent 8 times (12.8\%).

Slowing the attack of the opponent is also considered a successful result of the press. This allows the team to disrupt the organisation of play of the opposing team and also eliminates the element of surprise and helps the defending team to organise its defence better. In this area the most active teams were SU - it did it 7 times (12.7\%) and MGU - 6 times (9.6\%) in their matches against NSA. The NSA team did this 1 time (1.92\%) and 4 times (10\%) in its matches against SU and MGU respectively which shows it did not successfully use pressing to achieve this goal (Table 1). 
Table 1. Distribution of press types

\begin{tabular}{|c|c|c|c|c|c|c|c|c|c|c|c|c|c|c|c|c|c|c|c|c|c|c|}
\hline \multirow[t]{2}{*}{ 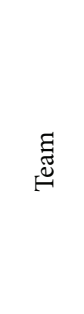 } & \multirow[t]{2}{*}{ 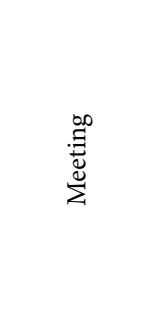 } & \multicolumn{2}{|c|}{ 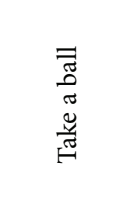 } & \multicolumn{2}{|c|}{ 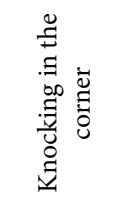 } & \multicolumn{2}{|c|}{ 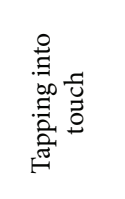 } & \multicolumn{2}{|c|}{$\begin{array}{l}7 \overline{7} \\
0 \\
3 \\
0 \\
0 \\
4 \\
4\end{array}$} & \multicolumn{2}{|c|}{$\bar{Z}$} & \multicolumn{2}{|c|}{ 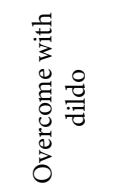 } & \multicolumn{2}{|c|}{ 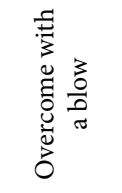 } & \multicolumn{2}{|c|}{ 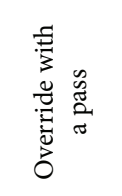 } & \multicolumn{2}{|c|}{ 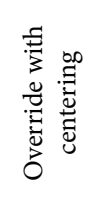 } & \multicolumn{2}{|c|}{ 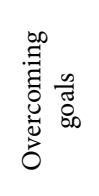 } & \multirow[t]{2}{*}{ 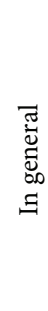 } \\
\hline & & 豆 & $a^{\circ}$ & 完 & $d^{\circ}$ & 豆 & $a^{\circ}$ & & $a^{0}$ & 完 & $d^{\circ}$ & 夏 & $a^{0}$ & 豆 & $a^{e}$ & 完 & $a^{e}$ & 咅 & $\alpha^{\circ}$ & 妾 & $a^{\circ}$ & \\
\hline \multirow{2}{*}{ NSA } & 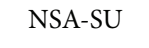 & 12 & 30 & 2 & 5 & 6 & 15 & 4 & 10 & 6 & 15 & 2 & 5 & 1 & 2.5 & 3 & 7.5 & 4 & 10 & 0 & 0 & 40 \\
\hline & NSA-MGU & 16 & 30.8 & 3 & 5.77 & 10 & 19.4 & 1 & 1.92 & 7 & 13.6 & 3 & 5.8 & 2 & 3.6 & 4 & 7.7 & 6 & 11.5 & 0 & 0 & 52 \\
\hline SU & NSA-SU & 15 & 27.3 & 4 & 7.28 & 18 & 32.7 & 7 & 12.7 & 5 & 9.09 & 1 & 1.82 & 3 & 5.46 & 2 & 3.65 & 0 & 0 & 0 & 0 & 55 \\
\hline MGU & NSA-MGU & 8 & 12.8 & 8 & 12.8 & 20 & 32.3 & 6 & 9.6 & 12 & 19.7 & 2 & 3.2 & 0 & 0 & 6 & 9.6 & 0 & 0 & 0 & 0 & 62 \\
\hline
\end{tabular}

In regards to forcing the opponent to clear the ball ness - 90.4\% in the match against MGU and $85 \%$ outside the field for a throw-in, the most active in the match against SU. The NSA team showed low teams were MGU - 20 times (32.3\%) in their match activity in terms of pressing attempts - it made 52 against NSA, and SU - 18 times (32.7\%), also in such attempts against MSU and 40 against SU. The their match against NSA (Table 1$)$.

One of the main features of the play of MGU is making plenty of tactical fouls - it was done 12 times. (19.7\%). The NSA team committed 7 such fouls (13.6\%) in their match against MGU and 6 such fouls (15\%) in the match against $\mathrm{SU}$. The SU team committed only 5 fouls $(9.09 \%)$ in their match against NSA (Table 1$)$.

The tactical maturity of the teams was shown by the fact that the number of unsuccessful pressing attempts were relatively few and harmless - they were mostly bypassed by means of a dribble or a pass. play of MGU featured a large number of failed pressing attempts (22.6\%) in their match against NSA.

Several things in regards to the distribution of pressing by zones deserve highlighting. First, the play of NSA is characterised by focusing the pressure over the opponent mostly in the middle of the field (zone 2) $-62.5 \%$ against $S U$ and $63.5 \%$ against MGU respectively. The SU team prefers to press in its own third of the field $-52.7 \%$ (zone 1), while the MGU team shows similar figures for pressing in its own half (53.2\%) and in the middle of the field (45.2\%) (Table 2). The NSA team was the one which pressed the most in Zone 3 - it executed pressing 7 and 8 times in its Table 2 shows the distribution of the pressing of the matches against SU and MGU respectively, or 17.5\% studied teams by effectiveness and by zones of the and $15.4 \%$. The MGU team was the one who used field. The NSA team showed the highest effective- pressing the least times in this zone $-1.6 \%$ (Table 2).

Table 2. Area distribution and efficiency

\begin{tabular}{|c|c|c|c|c|c|c|c|c|c|c|c|c|}
\hline \multirow[t]{2}{*}{$\underset{\widetilde{\varpi}}{\tilde{E}}$} & \multirow{2}{*}{ 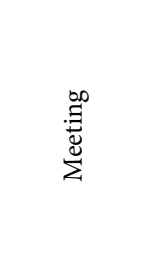 } & \multicolumn{2}{|c|}{$\begin{array}{l}\vec{\Xi} \\
\stackrel{\Xi}{0}\end{array}$} & \multicolumn{2}{|c|}{$\begin{array}{l}\sim \\
\tilde{\Xi} \\
N\end{array}$} & \multicolumn{2}{|c|}{$\begin{array}{l}m \\
\cong \\
\tilde{\Xi} \\
\text { N }\end{array}$} & \multicolumn{2}{|c|}{ 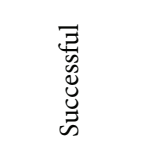 } & \multicolumn{2}{|c|}{ 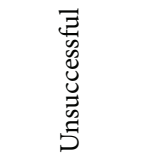 } & \multirow{2}{*}{ 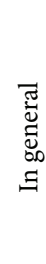 } \\
\hline & & 竞 & $\therefore$ & 妾 & $a^{\circ}$ & 妾 & $a^{\circ}$ & 妾 & $\therefore$ & 妾 & $\therefore$ & \\
\hline \multirow{2}{*}{ NSA } & NSA-SU & 8 & 20 & 25 & 62.5 & 7 & 17.5 & 34 & 85 & 6 & 15 & 40 \\
\hline & NSA-MGU & 11 & 21.1 & 33 & 63.5 & 8 & 15.4 & 47 & 90.4 & 5 & 9.6 & 52 \\
\hline SU & NSA-SU & 29 & 52.7 & 21 & 38.2 & 5 & 9.1 & 43 & 78.2 & 12 & 21.8 & 55 \\
\hline MGU & NSA-MGU & 33 & 53.2 & 28 & 45.2 & 1 & 1.6 & 48 & 77.4 & 14 & 22.6 & 62 \\
\hline
\end{tabular}

Our main criteria for successful execution of pressing cuted in each of the matches during the 6 time peis the ability of the teams to maintain a high pressing riods into which the duration of the match has been activity throughout the whole football match. divided for this study, as well as the aggregate reTable 3 shows the distribution of the pressing exe- sults for the first and the second half of the matches. 
Table 3. Distribution of the press in the course of the football matches

\begin{tabular}{|c|c|c|c|c|c|c|c|c|c|c|c|c|c|c|c|c|c|c|}
\hline \multirow[t]{2}{*}{ 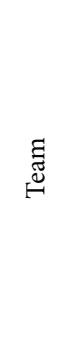 } & \multirow[t]{2}{*}{ 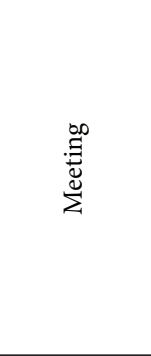 } & 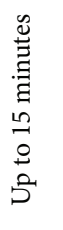 & & 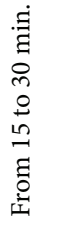 & & 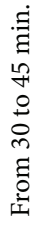 & & 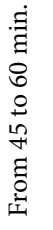 & & 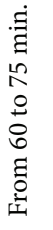 & & 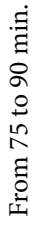 & & 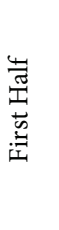 & & 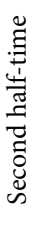 & & \multirow[t]{2}{*}{ 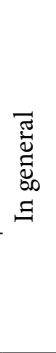 } \\
\hline & & 冧 & de & $\underset{\Xi}{\Xi}$ & de & 㤩 & de & 亮 & de & 鸹 & de & $\underset{\Xi}{\Xi}$ & de & $\underset{\Xi}{\Xi}$ & de & 冧 & de & \\
\hline \multirow{2}{*}{ NSA } & NSA-SU & 8 & 20 & 7 & 17.5 & 7 & 17.5 & 6 & 15 & 7 & 17.5 & 5 & 12.5 & 22 & 55 & 18 & 45 & 40 \\
\hline & NSA-MGU & 10 & 19.2 & 9 & 17.3 & 8 & 15.4 & 8 & 15.4 & 9 & 17.3 & 8 & 15.4 & 27 & 51.9 & 25 & 48.1 & 52 \\
\hline SU & NSA-SU & 11 & 20 & 9 & 16.4 & 8 & 14.5 & 10 & 18.2 & 10 & 18.2 & 7 & 12.7 & 28 & 50.9 & 27 & 49.1 & 55 \\
\hline MGU & NSA-MGU & 17 & 27.4 & 10 & 16.1 & 8 & 12.9 & 12 & 19.3 & 9 & 14.5 & 6 & 9.8 & 35 & 56.5 & 27 & 43.5 & 62 \\
\hline
\end{tabular}

During the first 15 minutes of the studied games there were between 8 (during the NSA - SU game) and 17 pressing attempts (NSA - MGU). Compared to the total number of pressing attempts, these are $20 \%-27.4 \%$ (Table 3). During the second 15 minutes the pressing activity of NSA decreases a bit and is around $17 \%$. We see the same trend in the teams of SU (16.4\%) and MGU (16.1\%). The data show that the teams of SU and MGU decrease their level of pressing just a bit to $14.5 \%$ and $12.9 \%$ respectively, while the NSA team maintains the tendency of pressing the opponent from the second $15 \mathrm{~min}$ utes. After the half-time break the team again start with higher pressing activity, especially MGU in the match against NSA $-19.3 \%$. It is notable that between the 45th and 60th minutes and between 60th and 75th minute the NSA and SU teams press with the same frequency, while the MGU team lowers the frequency of pressing halfway through the second half compared to its beginning. The data for the final 15 minutes shows that depending on the result and their physical conditioning the teams reduce the amount of pressing they do to the opponent. An exception to this is the NSA team in the match against MGU where it maintained its pressing frequency throughout the whole of the second half.

The aggregation of the cited values for the two halves of each match show that in the beginning of the matches all teams executed a lot of pressing actions, but as the matches went on their frequency decreased. An exception to this is the NSA team which tries to press steadily from the 1st to the 90th minute (Table 3).

\section{Conclusions}

In our opinion pressing is one of the decisive fac- tors for achieving high sport results in football. The data gathered from registering the pressing used by footballers who play at all kinds of levels, allow us to characterise in detail the defensive actions of the respective teams. The observed differences prove that the effectiveness of the pressing is a factor which impacts the end result of the games and may be use to evaluate the level of performance of a certain team.

The play of the NSA team is characterised by a lot of pressing activity, performed mostly in the middle of the field $-62.5 \%$ and $63.5 \%$ respectively in the matches against $\mathrm{SU}$ and MGU. The SU team prefers to press in its own third of the field $-52.7 \%$, while the MGU team shows similar figures for pressing in its own half (53.2\%) and in the middle of the field (45.2\%).

The main goal and the most effective end of the pressing is taking the ball from the opponent. The NSA team had the highest number of these by taking the ball from the opponent 16 times (30.8\%) during its match against the MGU and 12 times during its match against SU (30\%). The teams of SU and MGU were forced to clear the ball for a throwin, $32.7 \%$ and 32.3 respectively, as well as for a corner kick, $7.27 \%$ and $12.8 \%$ respectively. A main feature of the play of MGU is making plenty of tactical fouls - it was done 12 times (19.7\%), while the NSA and SU teams do not use this tactic much.

In regards to pressing during the different time periods of the two halves, it should be noted that only the NSA team pressed steadily from the 1 st to the 90th minute, which indicates that its players are very well prepared physically. The NSA team is also the best example of good use of the pressing be- 
cause of its high effectiveness of pressing throughout the whole match against MGU $-90.4 \%$.

Based on the study we conducted, we would like to recommend an increase in the number of practical sessions for the players of SU and MGU in order to improve the functional condition of the students from their representative football teams. By optimising and directing the training process towards improving the pressing actions of the footballers from the two teams they may achieve better homogeneity and tactical discipline during their future matches of the National University Football Championship.

\section{References}

Ангелов, В. и кол. (1987). Футбол. [Football.] C. Атанасов, Е. (2005). Изследване на пресата, прилагана от Българския национален отбор по футбол - жени на Международния турнир „Албена, 2005 г.“. [Research of the press applied by the Bulgarian national football team - women at the International Albena Tournament, 2005.]. Първа научна конференция за магистри и докторанти - 13-ти май 2005 г. Науката на младите специалисти. НСА „Васил Левски“. Център по ОКС „Магистри“. Отдел „Докторанти“. Сборник доклади, 73-80, С. НСА ПРЕС.

Атанасов, Е. (2010). Изследване на пресата, прилагана от Българския национален отбор по футбол - жени, в Световните квалификации. [Research of the press applied by the Bulgarian National Women's team in the World Qualifications.]. Пети международен научен конгрес. Спорт, стрес, адаптация. НСА “Васил Левски“. Спорт и наука. Извънреден брой. 87-91, Част II.

Бъчваров, М., Л. Димитров, А. Гигов (2008). Футбол, преса, кондиция, натиск. Кратка история и много упражнения. [Football, press, condition, pressure. Brief history and many exercises.]. С. Издателство: HCAПрес, НСА „Васил Левски“.

Гигов, А. (1999). Пресата във футбола. [The press in football.]. Спорт и наука, 4,5, 109-111, Vol. XLIII.
Гигов, А., В. Гигова (2000). Изследване на плътното персонално покритие (пресата) като основно защитно действие във футбола. [Investigation of tight personal cover (press) as a major protective action in football.]. Спорт и наука, 3, 13-24, Vol. XLIV.

Гигов, А. (2002). Изследване и усъвършенстване на пресата, прилагана от елитни футболисти. [Research and improvement of the press, implemented by elite players.]. Дисертационен труд. С. НСА „Васил Левски“.

Гигов, А. (2004). Пресата във футбола. [The press in football.]. С. Издателство „Авангард Прима“.

Гигов, А., В. Гигова, Л. Кръстев, В. Гаврилов (2004). Влияние на пресата върху класирането на отборите, финалисти на световното първенство по футбол в Япония и в Южна Корея. [Impact of the press on the ranking of the finalists of the World Cup in Japan and South Korea.]. Спорт и наука, 1, 55-62, Vol. XLVIII.

Червеняков, М. \& Цолов, Б. (1999). Тактика за добрия футбол. Пресирай - отнемай топката! [Тасtics for good football. Press - Remove the ball!]. Книга 1. С. Издателство „Спокон“.

Червеняков, М. \& Цолов, Б. (2000). Тактика за добрия футбол. Подсигурявай - съдействай за отнемане на топката! [Tactics for good football. Secure - help to remove the ball!]. Книга 2. С. Издателство „Спокон“.

Червеняков, М. \& Цолов, Б. (2001). Тактика за добрия футбол. Покривай - подготвяй отнемането на топката! [Tactics for good football. Cover - Prepare the removal of the ball!]. Книга 3. С. Издателство „Спокон“.

Шишков, А. и кол. (1992). Футбол - учебник за студентите от HCA. [Football - A textbook for the students of the National Sports Academy.] С. Ми Ф.

For correspondence:

Assoc. Prof. Georgi Ignatov, $\mathrm{PhD}$

Assoc Prof. Emil Atanasov, PhD

Sofia University "St. Kliment Ohridski”

National Sports Academy „Vassil Levski“

Department of sport

Department "Football and tennis"

E-mail: gochev730626@abv.bg

E-mail: atanasov78@abv.bg 